\title{
Performance Appraisal of Employees in Tertiary Institutions: A Case Study of University of Education, Winneba (Winneba Campus)
}

\author{
Marian Stephanie Davis (Corresponding Author) \\ Faculty of Business Studies \\ Takoradi Technical University \\ Takoradi, Ghana \\ E-mail: dmzaps@yahoo.com
}

\author{
Matilda Arko Mensah "Co-Author" \\ School of Graduate Studies \\ University of Education, Winneba, Ghana \\ E-mail: mensah.matilda@yahoo.com
}

Received: Feb. 10, 2020 Accepted: Mar. 17, 2020 Online published: May 12, 2020

doi:10.5296/ijhrs.v10i2.16409ＵRL: https://doi.org/10.5296/ijhrs.v10i2.16409

\begin{abstract}
The study sought to examine the performance appraisal of employees in tertiary institutions: a case of University of Education, Winneba (Winneba Campus). The descriptive survey design with quantitative approach was applied. Stratified and proportionate sampling were used to select respondents which included junior, senior staff and senior members of the university. Questionnaires were used to collect data for the study and the responses were analysed by frequency and percentages, line graphs, pie charts, means and standard deviations. The study revealed challenges such as fairness of evaluation decisions and lack of knowledge and skills of appraisers affect the conduct of performance appraisal. Also, employeese $^{\text {ee }}$ performance and developmental needs contribute to making performance appraisal effective. Evaluating employees ${ }^{\text {ee }}$ performance is ranked higher in performance appraisal. Again it was revealed that motivation affects performance appraisal and that the UEW appraises its staff annually. HODs are the highest appraiser category in the UEW. Lastly, the findings showed that performance appraisal in the University has succeeded in
\end{abstract}


identifying staff performance needs as very moderate. Recommendations were made based on the prompt implementation of effective staff performance appraisal systems and the need to improve on the mechanism to address and meet the performance needs of employees.

Keywords: performance appraisal, performance management, tertiary institutions, senior staff, senior members, junior staff, performance

\section{Introduction}

Employee appraisals when used appropriately can be an extremely powerful tool to aid an organisation to mobilize the energy of every employee in achieving the organisation's goals. The concept of performance appraisals is not necessarily an end, but they are seen as very important means to measure, explore problems and also monitor organisational progress. This makes performance appraisal a supporting system for the delivery and improvement of output. As supporting mechanisms, appraisal systems must be designed in such a way as to facilitate organisational activities.

Performance appraisal primarily focuses on every individual and getting the maximum out of an employee throws a big challenge to today managers. What is to be done therefore, is to provide adequate motivation to employees in giving out their maximum best. Currently, some gaps in higher education concerning the concept of performance appraisal has created controversies. The areas that are believed to have created these controversies include self-interest, politics as well as organisational conflicts. These affect the fair conduct and effectiveness of performance appraisal systems. This is critical because, if the systems that are used throughout the conduct of appraisal are not fair and efficient, it becomes much of a trouble due to the fact that in higher educational institutions, employees ${ }^{\text {ee }}$ performance go a long way to shape the culture as well as the quality of academic work and output.

It should be pointed out that appraising employees is very important in higher educational institutions. Colleges and universities which are knowledge-based institutions specifically depend on the rich knowledge, expertise, commitment and innovation of their staff. Simmons (2002) have indicated that, performance appraisal can be a system that collectively addresses issues surrounding pay and conditions of employees and particularly negotiate between employees and their managers. A good appraisal system therefore provides managerial decisions such as allocation of responsibilities and duties, pay, employees' empowerment and level of supervision. It also addresses issues relating to promotions, training, development, needs and termination of appointment (Mullins, 2005). Staff performance appraisal is used for administrative and development purposes.

Administratively, performance appraisal provides input to be used for all human resource activities such as documenting personnel decisions, transfers, promotions, layoffs, decision making, making rewards and compensation decisions, retention and termination of staff etc. In the area of development, it provides feedback on performance, identifying individual strengths and weaknesses, assisting in goal(s) identification, improving communication, identifying training needs and also providing interaction between managers and employees and reinforcing authority structure and recognizing individual performance. 
The processes that are entailed in performance appraisal varies from organizations to organisations. In some instances, the personality, behaviours, as well as job performance are sometimes measured both quantitatively and qualitatively (Torrington et al., 2005). As indicated by Torrington et al. (2005), the concept of performance appraisal is very important, it also yield unsatisfactory results in that, there seem to be a negative point of view which always create a dissatisfaction between employees and employers. Areas that create controversies include lack of feedback and performance review session regarding employees stand the chance of creating appraisal malfunction (Heathfield, 2000). According to Smith (1990), poor training for appraisers can also render the process of performance appraisal ineffective.

Although it is recognised by most countries and institutions that appraising employees serves as the way to effectively manage human resources and attaining higher organisational effectiveness and efficiency, there is still confusion regarding how it should be conducted, evaluated and managed for the desired results. From the view of Agyenim-Boateng (2006), one of the answers in solving some of the problems facing the public sector universities has to do with the ability of managers to quicken work behaviours in order to meet the demands of clients and promote desired behaviour to fulfill individual and corporate objectives.

In the University of Education (Winneba campus), only a handful of staff for the past few years have attached importance to the performance appraisal process. This is because, all categories of staff (junior staff, senior staff, senior members - both teaching and non-teaching) upon a request by the Division of Human Resource are supposed to download appraisal forms from the University's website for individual performance appraisal and submission. Further investigations revealed that no such request or reminders have been circulated for the past two to three years for this exercise.

\section{Objective and Research Questions}

This study seeks to find out whether performance appraisal system (PAS) in tertiary institutions, particularly in the University of Education, Winneba, is in accordance with effective performance appraisal system (EPAS). Specifically, the following research questions were formulated in line with the specific objectives of study to serve as a guide to the study:

1. What challenges confront management of UEW in conducting staff performance appraisal in the UEW, Winneba Campus?

2. What are the factors and their ranks that contribute to an effective staff performance appraisal in UEW, Winneba Campus?

3. How often does the University of Education, Winneba Campus, appraise their staff?

4. To what extent has performance appraisal in the UEW, Winneba Campus has succeeded in identifying staff performance needs?

The study will provide a thorough account of the performance appraisal of staff in University of Education, Winneba (Winneba campus) with the view to providing material and direction 
for future development.

\section{Literature Review}

\subsection{The Concept of Performance Appraisal}

According to Singh (2004), performance appraisal can be done in every three to six months, and certainly not less frequently than every twelve months. In actual fact, appraisals are undertaken to expose an employee to his/her performance. This is done to measure his or her output in accordance with the supervisor's expectations in detecting areas that need more training and development. In all these, the employees have the timely right to know the rudiments of the entire processes while appraising and analysing their performance.

\subsection{Performance Appraisal Systems in Academic Institutions}

The extent to which Performance Appraisal Systems have been introduced within universities varies widely Ampah (2015), citing Agyenim-Boateng (2006) gave an example that, the United Kingdom and Ghana introduced Performance appraisal system in their universities following directives by governments. Performance appraisal was introduced into the Ghanaian public sector universities in the mid-1970s following directive by the government that all public institutions must introduce an Annual Confidential Report (ACR) for their workers. Similarly, Performance appraisal was introduced into British universities in 1998 following Gariatt Report, Ampah (2015).

According to Agyenim-Boateng (2006) the Gariatte Report revealed that the aim of performance appraisal in the British universities has been to increase control and responsibility of academics. Consequently, appraisal is seen as part of management accepted view that there should be some means by which performance can be observed, calculated and regulated. Agyenim-Boateng citing Wilson, (2002) stated that "the appraisal arose out of national agreement as part of a pay settlement and represented policy of government to introduce appraisal in education. Accordingly, national guidelines for appraisal were agreed upon but individual universities were allowed to draw their own procedures for the introduction and implementation of university-wide performance appraisal which ought to be judgmental in model".

Looking at the recognition that has been given to performance appraisal, there are uncertainties regarding the constituent of effective appraisals and how they should be conducted in higher academic institutions (Khoury \& Analoui, 2004). Due to the intense economy and technological changes as well as the existence of knowledge transfer, increasable customer demands and awareness, universities are required to ensure quality in everything they do. Public universities therefore need to change from the only teaching and studying. They are to ensure that they supply the limited industry with highly competent and employable graduates who will be in position to withstand the challenges that come with economic changes and highly competitive environment (Karuhanga \& Werner, 2013). Undoubtedly, this can be achieved through possible successful implementation of a performance appraisal system. 


\subsection{Purpose of Performance Appraisal}

Performance appraisal can serve numerous purposes and prominent among them is to support personnel decisions, promote outstanding, to expose performers and to train, transfer and discipline employees, among others. Appraisals are used as input for administering formal rewards and punishments in organisations. Since test results are often correlated in appraisal results, appraisals are used as criteria in test validation which consequently provides feedback to employees. The importance of this is that appraisal serves as vehicles for personal and career development (Karuhanga \& Werner, 2013).

In addition, appraisals help in the establishment of objectives for training programmes purposes. Diagnosing of organizational problems can be done using appraisal. This is done an individual identifies the training needs, knowledge, abilities and skills when it comes to hiring that individual. Furthermore, according to Ampah (2015), appraisal helps to distinguish between effective and ineffective performers in that, it represents the beginning of a process, rather than an end product. In this sense, when appraisal is not conducted carefully and properly, performance results are negatively influenced, appraisals cannot be used legitimately for its intended purpose or (Cascio, 1996).

\subsection{Challenges of Staff Performance Appraisal}

There are a number of challenges involved in performance appraisal. One such challenge is the distorting effects such as halo effects, central tendency, crony effects, and Veblen effects (Agyenim-Boateng 2006). According to Ayenim-Boateng (2006), these effects do not only distort the appraisal results but also make the results less useful when it comes to making decisions on promotion, salary, identification of training and development needs and counseling.

According to Derek et al (2005), several factors create a challenge for effective appraisal systems. Prominent among these factors according to Longenecker (1997) are unclear performance criteria or an ineffective rating instrument, poor working relationships with the boss and lack of information on the manager's actual performance, lack of focus on management's development or improvement and pay. In addition, factors such as problems with the process used in appraisal, lack of appraisal skills and lack of structure or substance also affect the conduct of appraisal negatively (Longenecker, 1997).

According to Longenecker (1997), the ownership of appraisal system is also important. It was uncovered that when ownership is designed and imposed on the human resource function, line managers will be faced with the problem of little ownership. In essence, majority of employees feel that appraisal is just a form-filling exercise for someone else's benefit which does not come with any practical value to performance within the job and hence its irrelevance. It should be said that the result of appraisal can yield an unsatisfactory result due to the procedure through which it is conducted.

As a result, problems such as lack of employees' participation and involvement in the process especially in establishing their job targets are often unclear, unfeasible or non-existent. A lot more can be talked about regarding feedback and performance review sessions with 
employees and poor appraisers' training can cause ineffectiveness in some institutions (Smith, 1990).

Some supervisors in the view of Abrefa-Gyan, (2010) are lenient while others can be harsh when rating their subordinates. Some supervisors may also be tempted to exhibit some forms of biases based on a person's gender, religion or nationality. In some circumstances, these raters may assign higher ratings to senior employees because of the relationship they have in common.

In summary, it has been noted that performance appraisal systems fail as a result of the lack of managing the system effectively or lack of management support. Ofori and Atiogbe (2011) have stressed that leadership in higher learning institutions fail to implement performance appraisal systems and that universities in Ghana face a number of challenges. These include but not limited to inadequate funding, poor work culture among staff, lack of rewards and lack of a clear performance appraisal system which go a long way to affect the quality of performance appraisal.

\subsection{Who Appraises Employees' Performance?}

There are a number of standards or criteria that are used in appraising employees' performance. In some cases, multiple candidates used in appraising the performance of an employee while in other cases one person (even though it is unrealistic to fully observe and evaluate) can be used to do the appraisal depending on the complexity of the jobs. In actual fact, appraisal can be conducted by anyone who is familiar with the performance of the employee under question. Mathis and Jackson (2004) suggested that appraisal can be done by the following persons or group of persons:

\section{Supervisors who rate their employees \\ Employees who rate their superiors \\ Team members who rate each other \\ Outside sources or evaluators, \\ Employees' self-appraisal, and \\ Multi-source appraisal}

\subsection{Uses of Performance Appraisal}

Generally, appraisals are used by organizations for two distinct roles. First and foremost, appraisals are used to measure the performance of employees for the aim of making administrative decisions such as pay and promotion. Secondly, appraisals are used to develop the employee. Managers of organisations use appraisal to make vibrant decisions on compensation, promotion, dismissal, downsizing and layoffs (Mathis \& Jackson, 2004). Developmental uses of performance appraisal on the other hand include identifying employees' weaknesses and strengths, identifying areas for growth, developmental planning as well as coaching and career planning (Mathis \& Jackson, 2004).

\subsection{Methods/Techniques of Performance Appraisal}

The traditional and new approaches to performance appraisal use different methods or 
techniques in assessing performance of the individual worker. The most commonly used methods or approaches are rating methods, essay method, trait ratings, peer ranking, organizational records, critical incidents, behaviourally based scales and behaviourally anchored, objectives and goals setting procedures. Hansen (2003) Jackson and Mathis (1994), Swan (1991), Teel (1977) and Oberg, (1972) also stated that the most commonly used methods of performance appraisals are; rating scales, essay and results oriented or MBO methods.

\subsection{Theoretical Framework}

There are various theories of performance management but for the purpose of this study, the equity theory by Adam (1963), procedural justice theory by Thibaut and Walker (1975) and expectancy theory by (Vroom, 1964) discussed.

\subsection{The Equity Theory}

This theory is premised on the point that an employee perceives the relationship between outcomes, what the said employee receives from a job and the oragnisation, as well as the major inputs. It also talks about what the employee contributes to a job and the organization (Adam, 1963). It should be stressed that outcomes of an employee include pay, benefits, job satisfaction, status, opportunities for advancement prestige and job security (Adam, 1963). Inputs similarly talks about the contribution made which include units produced, education, work experience and others that an employee perceive that contribute to the well-being of the organization. According to Adam (1963), equity theory is concerned with outcomes and inputs as they are perceived by the employees involved and are not merely based on any specific standards. As a result, inasmuch as equity theory allows employees to compare their inputs and outcomes to others and judge the equitableness of these relationships in the form of ratio, it deepens the fact that, when employees are appraised, their outcomes as compared to other are made obvious, hence the relevance of the theory.

\subsubsection{Procedural Justice Theory}

According to George and Jones (1999), this theory is concerned with the perceived fairness of the process that are used in making decisions about the distribution of outcomes. These decisions pertain to how performance levels are evaluated, how disputes are solved, and how outcomes are distributed across employees. In this theory, employees are key and thus, their reactions to procedures depend on how they perceive the procedures rather than what the procedures actually mean (Thibaut \& Walker, 1975).

The theory maintains that employees are motivated to perform at a high level when they perceive that the processes that are used to make decisions about their outcomes are fair, their motivation is considered as well as if they feel their performance will be assessed play a recommendable role in the organization. In essence this theory seeks to explain what causes workers to perceive procedures as fair or unfair and the consequences of these perceptions (Thibaut \& Walker, 1975).

The theory is very essential to the study due to the fact that, in carrying out that performance 
appraisal of employees effectively, there are series of systems and methods through which the conduct of appraisal cannot be done. In doing this, there must fairness through out the conduct of performance appraisal for its effectiveness.

\subsubsection{Expectancy Theory}

As indicated by Vroom (1964), employees' performance is based on individual factors such as personality, skills, knowledge, experiences and abilities. The theory maintains that, although individuals may have diverse set of goals, they can be motivated if they believe that there is a positive correlation between effort and performance and that favourable performance will be rewarded (Vroom, 1964). In essence the theory is centered on valence which refers to the emotional orientations people have about their outcomes, instrumentation which focuses on perceptions of employees that they will get what they actually desire whereas expectancy suggests that employees have different expectations and levels of confidence about what they are capable of doing and management must discover that resources, training, or supervision employees need (Vroom, 1964). In actual fact, the theory empahsises the concept of motivation which is seen as one of the major factors of employees; performance in every organization and hence, the relevance of this theory to the study.

\subsection{Empirical Review}

Ochoti et al (2012) study on factors that influence employees' performance appraisal system: a case of the ministry of state for provincial administration and internal security, Kenya. revealed that all the five factors that is implementation process, interpersonal relationships, rater accuracy, informational factors, and employee attitudes were positively related to the performance appraisal system. It was uncovered that about $55.1 \%$ of the variation in performance appraisal system can be explained by the changes in implementation process, interpersonal relationships, rater accuracy, informational factors and employee attitudes.

Another study by Begum, Hossain and Sarker (2015) on the factors that determine how effective performance appraisal system is in Bangladesh. (in the pharmaceutical industry) revealed rater accuracy and performance gaps, training and motivation, performance appraisal process, employee attitude, communication, and inter personal factors to influence the conduct of appraisal. It was uncovered that all the factors except interpersonal factor are significant when it comes to ensuring the effectiveness of performance appraisal system.

A similar study conducted by Ahmad and Bujang (2013) on the issues and challenges in the practice of performance appraisal activities in the $21^{\text {st }}$ century uncovered that factors such as lack as fairness of evaluation decision, appraiser bias, lack of required skills and knowledge, subjectivity in evaluation, the practice of quota system, criticism and comments for unions, and inability of appraisal to suit organizational culture serve as a challenge when appraising employees' performance.

Kim and Hoizer (2014) on public employees and performance appraisal: a study of antecedents to employees' perception of the process also revealed that the developmental use of performance appraisal, employee participation in performance, standard setting, the quality of the relationship they have with their supervisors, and employee perceived empowerment 
are positively associated with employee acceptance of performance appraisal.

Cintron (2009) on the performance appraisal systems in higher education: an exploration of Cristian institutions revealed that there was a high usage of staff performance appraisal in its population of 108 Christian colleges and universities. Cintron (2009) also uncovered that a significant amount of dissatisfaction with the appraisal process come to being due to lack of leadership support for the appraisal process, supervisors not being held accountable for the timely completion of their appraisals, and the lack of training provided supervisors for doing performance appraisals well.

\section{Materials and Methods}

\subsection{Research Design}

The descriptive research methodology was adopted for this study and a survey used to administer questionnaire to selected workers of the University of Education, Winneba, Winneba Campus due to the fact that, survey is an effective way to collect data from a wide range of respondents in a more systematic way.

As indicated by Creswell (2008), survey stands the chance of soliciting the views of wide range of subjects through the use of questions. It should be pointed out that descriptive surveys efficiently and effectively measure variables without necessarily increasing cost and allows data to be collected from numerous subjects at a relatively low cost and quickly though difficult in asking follow-up questions on responses.

\subsection{Population}

According to Davis et al., (2002), a population must have at least one or more characteristics in common. The target population consisted of three categories which included; junior staff, senior staff and senior members (administrative) of the University of Education, Winneba (Winneba campus) from various departments. In all there were four hundred and ninety-two (492) junior staff, three hundred and nine (309) senior staff and fifty-nine (59) senior members in administrative positions making a total of eight hundred and sixty (860) (Planning Unit, 2017).

\subsection{Sample and Sampling Techniques}

A sample size of 86 was used for this study based on the argument by Gay, Mills and Airasian (2009) that $10 \%-30 \%$ of the total study population is appropriate for a survey. Stratified sampling was used to collect data for junior, senior staff and senior members (Administrative). The stratified procedure was used because it is important to be accurate in one's estimation (Kumar, 1999). It also helps to save time and resources while making data confidence high. The Junior Staff, Senior Staff and Senior Members respectively as strata were randomly selected and administered with questionnaires. This technique was adopted for the study because it is convenient and facilitates quick data collection.

\subsection{Data Collection Instrument}

A self-developed questionnaire was the main data collection instrument used for the study. 


\section{Macrothink}

International Journal of Human Resource Studies

ISSN 2162-3058

2020, Vol. 10, No. 2

The use of questionnaires is very common in social sciences and it is increasingly being used in organizational studies (Sarantakos, 2005, 1998). As opined by McLean (2006), questionnaire is a set of questions that is carefully designed to be given to the same group of people in order to collect data about some topics that are of interest to researcher.

Using a questionnaire allows for a quick, easy and interpretable data more easily from large respondents without delaying unnecessarily, it was less expensive way to gather data from a large number of respondents. The administration of questionnaire was done by the researcher through personal visits to various departments, sections and directorates.

A four point Likert scale was used to measure the items in this section namely, $1=$ Strongly Disagree, 2 = Disagree, $3=$ Agree and $4=$ Strongly Agree with 1 indicating the least agreement to the items and 4 indicating the strongest agreement to the items. Section $\mathrm{C}$ was composed of ten items that sought to elicit responses on the factors that contribute to effective performance appraisal in University of Education, Winneba Campus. Section D also contained five items that sought to elicit reopens on how often does the University of Education, Winneba Campus appraise their staff.

\subsection{Validity and Reliability of the Instrument}

The content validity of the instrument was accessed by the researchers. In ensuring content representativeness, the questionnaire was assessed in the contest of ambiguity, clarity and correctives. With issues of reliability, a pilot test was conducted to check how consistent the items were. Cronbach Alpha reliability test was used to analyse the items which resulted a reliability coefficient of .79 which is good enough according to Pallant (2010). A 100\% response rate was attained and in all these, the researchers made efforts to take into consideration the issues confidentiality and anonymity of respondents.

\subsection{Data Analysis Techniques}

The collected data was edited, cleaned, arranged serially, coded and further subjected to statistical computations. The gathered data was analysed with the aid of Statistical Products of Service Solutions (SPSS). Percentages, tables and frequencies were used to analyse the background information of respondents. Descriptive statistics such as frequencies and percentages were used to analyse all the research questions. This was done to ascertain the percentages of respondents who chose each question based on the objectives of the study. Major findings were determined based on the data presented and linked to the reviewed literature. 


\section{Results}

Table 1. Demographic Characteristics of Respondents

\begin{tabular}{|lll|}
\hline Variables & Frequency & Percentages \\
\hline Age (in yrs.) & & \\
$20-29$ & 23 & 26.74 \\
$30-39$ & 37 & 43.02 \\
$40-49$ & 21 & 24.42 \\
$50-59$ & 5 & 5.81 \\
Gender & & \\
Male & 41 & 47.67 \\
Female & 45 & 52.33 \\
Highest Educational Level & & \\
SSCE/WASSCE & 2 & 2.33 \\
DIPLOMA & 8 & 9.30 \\
First Degree & 38 & 44.19 \\
Master's Degree & 38 & 44.19 \\
Length of Working Experience (in yrs.) & & \\
1-5 & 29 & 33.72 \\
6-10 & 33 & 38.37 \\
11-15 & 10 & 11.63 \\
16-20 Status in UEW & 14 & 16.28 \\
Junior Staff & & \\
Senior Staff & 23 & 26.74 \\
Senior Member (Administrative) & 42 & 48.84 \\
\hline
\end{tabular}

Source: Survey data, 2018

The data distribution of the respondents revealed that 5 (5.81\%) were within age 50-59 years and $21(24.42 \%)$ were within 40- 49 years. The age distribution revealed that over half of the respondents were aged between 20 and 39 years indicated by $60(69.76 \%)$. This means respondents were relatively young and hence considered as energetic and capable of communicating their perception of the performance appraisal system in the University of Education, Winneba.

45 respondents $(52.33 \%)$ were female while $41(47.67 \%)$ were male. Regarding the academic qualifications, data further revealed that 2 (2.33\%) held SSCE/WASSCE and 8 (9.30\%) held diploma while $38(44.19 \%)$ held master's degree and bachelor's degree respectively. This means that they have been adequately trained to occupy various administrative positions and hence are able to provide information on how performance appraisal system works.

Additionally, respondents have had considerable working experience. Accordingly, 29 respondents that is $(33.72 \%)$ had been in administrative profession for between 1 and 5 years, while $33(38.37 \%)$ had been in administrative profession for the duration of 6 to 10 years. Furthermore, 10 (11.63\%) respondents had between 11 - 15 years' work experience and 14 respondents represented by $(16.28 \%)$ had $16-20$ years of administrative experience. This is a relatively long experience in the profession which may have given the respondents knowledge and experience on the performance appraisal system procedures and challenges confronting management in appraisal of staff. 
Again, the data revealed that $23(26.74 \%)$ were junior staff, whiles majority $42(48.84 \%)$ were senior staff and 21 (24.42\%) were senior members (administrative). This means that the respondents stand the chance of providing information on the performance appraisal system procedures.

The analyses were based on the research questions that were set for the study.

\subsection{Research Question One}

What challenges confront management of UEW in conducting staff performance appraisal in the UEW, Winneba Campus?

The 4-point Likert type scale responses were coded into two (Responses 1 and $2=$ Disagreement, and 3 and $4=$ Agreement). The opinions of senior members (Administration), senior staff, and junior staff were sought on 10-items. The results are presented in Figure1.

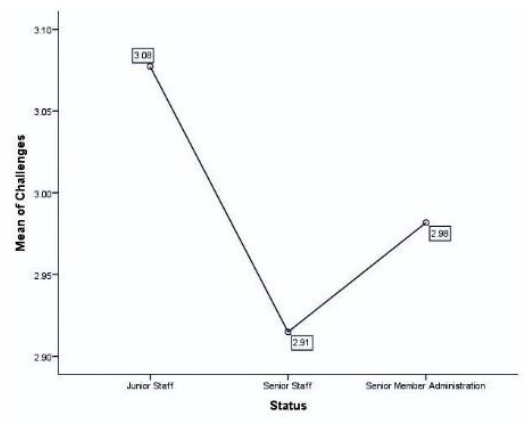

Figure 1. Management challenges in conducting performance appraisal for employees

Findings from Figure1 show that respondents had a split view on the 10-items with issues of disaffection resulting from the appraisal process and external indicators. For example, respondents mentioned fairness of evaluation decision $(\mathrm{M}=3.21, \mathrm{SD}=.71)$, discontentment between manger and appraise $(\mathrm{M}=3.15, \mathrm{SD}=.09)$, appraiser/appraise bias $(\mathrm{M}=3.15, \mathrm{SD}$ $=.76)$, inadequate knowledge and skills of appraisers $(\mathrm{M}=3.13, \mathrm{SD}=.55)$, and replacing organisational standards with appraisers' values and bias $(\mathrm{M}=3.09, \mathrm{SD}=.08)$ as the top five disaffections facing UEW management's performance appraisal.

However, the remaining 5-items recorded mean values below 3 ("agree") as external factors affecting the appraisal process at UEW. These are individuals work emphasis over team work $(\mathrm{M}=2.98, \mathrm{SD}=.90)$, time and emerging in completing the process $(\mathrm{M}=2.85, \mathrm{SD}=.08)$, organisational culture $(\mathrm{M}=2.83, \mathrm{SD}=.08)$, encourages safe behaviour as opposed to risk-taking $(\mathrm{M}=2.66, \mathrm{SD}=1.02)$, and access to appraisal form on the UEW web portal $(\mathrm{M}=$ $2.63, \mathrm{SD}=.94)$; and indication of disagreement. The implications for mean scores of 2 ("Disagreement) for the 5-items illustrates that employees rating the challenges facing UEW management did not believe that the institution's management of appraisal procedures should focus on these bottom 5-items.

Figure1 categorised the mean values. Amongst the three employee groups, an interesting phenomenon was observed amongst the three employees' categories. The highest mean values of 3.08 were recorded for the Junior Staff with 0.17 for Senior Staff- sharp drop with 0.07 rise 
for Senior Members (Administration). Approximately, the mean scores indicated "agreement" on the 10-items as challenges to management in this study. Perhaps, the junior staff categories suffered more disaffection than the senior staff in the institution, hence the curvilinear visual recorded in figure1. In all the result show that challenges such as fairness of evaluation decisions, discontentment between manger and appraisee, appraiser bias, lack of knowledge and skills of appraisers, access to appraisal forms, replacing organisational standards with appraisal values and time in completing appraisal process are the challenges of UEW, Winneba Campus in conducting appraisal. It was also uncovered that the junior staff categories suffered more disaffection than the senior staff in the institution when it comes to appraisal issues.

\subsection{Research Question Two}

What are the factors and their ranks that contribute to an effective staff performance appraisal in UEW, Winneba Campus?

Respondents were asked 10 items relating to the factors which contribute to the effective staff appraisal out of which they were to either agree or disagree to the statement. The result is presented in Table 2.

Table 2. Multiple Response-Items for Effective Use of PA Outcomes

\begin{tabular}{|c|c|c|c|c|c|c|}
\hline \begin{tabular}{|l|} 
Performance \\
Outcomes \\
\end{tabular} & Agree & $\begin{array}{l}\% \\
\text { Agree }\end{array}$ & Disagre & $\begin{array}{l}\text { \% } \\
\text { Disagree }\end{array}$ & Total & $\begin{array}{l}\% \\
\text { Total }\end{array}$ \\
\hline Evaluate employees' performance & 74 & 12.6 & 11 & 4.4 & 85 & 10.2 \\
\hline $\begin{array}{l}\text { Developmental needs of } \\
\text { employees }\end{array}$ & 73 & $\begin{array}{l}12.5 \\
125\end{array}$ & 13 & $\begin{array}{l}5.2 \\
52\end{array}$ & $\begin{array}{l}86 \\
86\end{array}$ & $\begin{array}{l}10.3 \\
103\end{array}$ \\
\hline Identify strengths of employees & 72 & 12.3 & 14 & 5.6 & 86 & 10.3 \\
\hline $\begin{array}{l}\text { Identify weakness of employees } \\
\text { Performance gaps }\end{array}$ & $\begin{array}{l}72 \\
59\end{array}$ & $\begin{array}{l}12.3 \\
10.1\end{array}$ & $\begin{array}{l}14 \\
24\end{array}$ & $\begin{array}{l}5.6 \\
9.7\end{array}$ & $\begin{array}{l}86 \\
83\end{array}$ & $\begin{array}{l}10.3 \\
10.0\end{array}$ \\
\hline $\begin{array}{l}\text { Control behaviour of employees } \\
\text { Motivation }\end{array}$ & $\begin{array}{l}52 \\
49\end{array}$ & $\begin{array}{l}8.9 \\
8.4\end{array}$ & $\begin{array}{l}28 \\
36\end{array}$ & $\begin{array}{l}11.3 \\
14.5\end{array}$ & $\begin{array}{l}80 \\
85\end{array}$ & $\begin{array}{l}9.6 \\
10.2\end{array}$ \\
\hline $\begin{array}{l}\text { Decision making on annual salary } \\
\text { increases }\end{array}$ & 34 & 5.8 & 44 & 17.7 & 78 & 9.4 \\
\hline Dismissals decisions & 28 & 4.8 & 51 & 20.6 & 79 & 9.5 \\
\hline Sum & 586 & 100 & 248 & 100 & 834 & 100 \\
\hline Average & 59 & 10 & 25 & 10 & 83 & \\
\hline
\end{tabular}

Source: Survey data, 2018

$$
\mathrm{N}=86
$$

The results from Table 2 show that majority (more than 50\%) of the respondents were of the view that evaluation of employee performance, developmental needs of employees, assessment of employees performance, identifying the strengths weaknesses of employees, performance gaps, control behaviour of employees and motivation contribute to making performance appraisal effective in the University of Education, Winneba. Meanwhile, factors such as decision making as annual salary increases and dismissal decisions do not contribute to making performance appraisal effective in the institution.

The second part of research question two was to elicit responses' on the ranks of the factors 
that contribute to performance appraisal of university staff of the University of Education, Winneba. Respondents were asked to rank in order, 10 items relating to the how they view performance appraisal in UEW as relevant to the conduct of PA. The results are presented in Table.3.

Table 3. Ranked Order of How Staff View Performance UEW

\begin{tabular}{|c|c|c|c|c|}
\hline \multirow{2}{*}{\multicolumn{2}{|c|}{ Items }} & \multirow{2}{*}{$\begin{array}{l}\text { Sum } \\
\text { Statistic }\end{array}$} & \multirow{2}{*}{$\begin{array}{l}\text { Mean } \\
\text { Statistic }\end{array}$} & \multirow{2}{*}{$\begin{array}{l}\text { Std. Deviation } \\
\text { Statistic }\end{array}$} \\
\hline & & & & \\
\hline 1 & Evaluate employees' performance & 286 & 3.36 & .800 \\
\hline 2 & Assess performance of employees & 279 & 3.24 & .702 \\
\hline 3 & Identify strengths of employees & 276 & 3.21 & .738 \\
\hline 4 & Developmental needs of employees & 273 & 3.17 & .770 \\
\hline 5 & Identify weakness of employees & 271 & 3.15 & .678 \\
\hline 6 & performance gaps & 254 & 3.06 & .802 \\
\hline 7 & Control behaviour of employees & 238 & 2.98 & .914 \\
\hline 8 & Motivation & 237 & 2.79 & 1.013 \\
\hline 9 & $\begin{array}{l}\text { Decision making on annual salary } \\
\text { increases }\end{array}$ & 183 & 2.35 & 1.091 \\
\hline & 0. Dismissals decisions & 168 & 2.13 & 1.017 \\
\hline & Iean & 246.50 & 2.94 & 0.85 \\
\hline
\end{tabular}

( $\mathrm{n}=86)$ Source: Survey data, 2018

Results in Table 3 show 60\% $(n=6)$ indicators were ranked as topmost factors as contributing the effective conduct a PA. These include evaluate employees' performance, developmental needs of employees, assess performance of employees, identify strengths of employees, identify weaknesses of employees and performance gaps. On the contrary, respondents indicated that $40 \%$ the last four factors are least ranked as contributing to effective PA. These are control behaviour of employees, motivation, decision making on annual salary increases and dismissal decisions.

\subsection{Research Question Three}

How often does the University of Education, Winneba Campus, appraise their staff?

This research question elicited employees' views on how often the University of Education, Winneba appraise its staff. The results are presented in Tables 4, 5 and 6. 
Table 4. Frequency of Performance Appraisal According to Employees' Status

\begin{tabular}{|lllllll|}
\hline Frequency & $\begin{array}{l}\text { Junior } \\
\text { Staff }\end{array}$ & $\begin{array}{l}\text { Senior } \\
\text { Staff }\end{array}$ & \multicolumn{2}{l}{$\begin{array}{l}\text { Senior } \\
\text { (Administration) }\end{array}$} & Total & \% Total \\
\hline Once a year & 15 & 36 & 21 & 72 & 84 \\
\hline Twice a year & 7 & 4 & 0 & 11 & 13 \\
\hline Thrice a year & 1 & 0 & 0 & 1 & 1 \\
\hline Four times a year & 0 & 2 & 0 & 2 & 2 \\
\hline Total & $\mathbf{2 3}$ & $\mathbf{4 2}$ & $\mathbf{2 1}$ & $\mathbf{8 6}$ & $\mathbf{1 0 0}$ \\
\hline
\end{tabular}

Source: Survey data, 2018

Results in Table 4 reveal that annual performance appraisal has been dominant at the University of Education, Winneba (see Table 3, thus, 84\%, $\mathrm{n}=72$ ). However, the current study showed outliers (extreme scores in a distribution) in respondents' views on how often the institution administer performance appraisal. Between twice and four times constituted $14 \%$ of respondents views and this could be interrogated further. For instance, the 14\% respondents might not be aware of what constitute performance appraisal at their units.

Table 5. Working Cycle and Appraisal Practices

\begin{tabular}{|lcccc|}
\hline Time & Freq. & \% & Cumulative \% \\
\hline At the end of the year & 69 & 80.2 & 80.2 \\
Beginning of the year & 11 & 12.8 & 93.0 \\
In the middle of the year & 4 & 4.7 & 97.7 \\
When one is due for 2 & 2.3 & 100 \\
promotion & & & & \\
\hline Total (n) & $\mathbf{8 6}$ & $\mathbf{1 0 0}$ & \\
\hline
\end{tabular}

Source: Survey data, 2018

The second procedure examined in this study involved the working cycle of the year performance appraisal is conducted for workers. Table 4 shows that $80 \%(n=69)$ of respondents indicated the end of the year with $13 \%(\mathrm{n}=11)$ of the workers reporting beginning of the year. Marginally, $7 \%(n=6)$ of respondents believed that mid-year and promotion times were occasions their supervisors appraised them. Similar to outlier scores observed in Table 3, such cases of PA practices might exist with superiors not observing the institution's programmers for appraising employees. Issues of staff HR orienting supervisors and employees on PA protocols are possible in the context of the current study. 
Table 6. Appraisers of Employee Categories at the Workplace Status

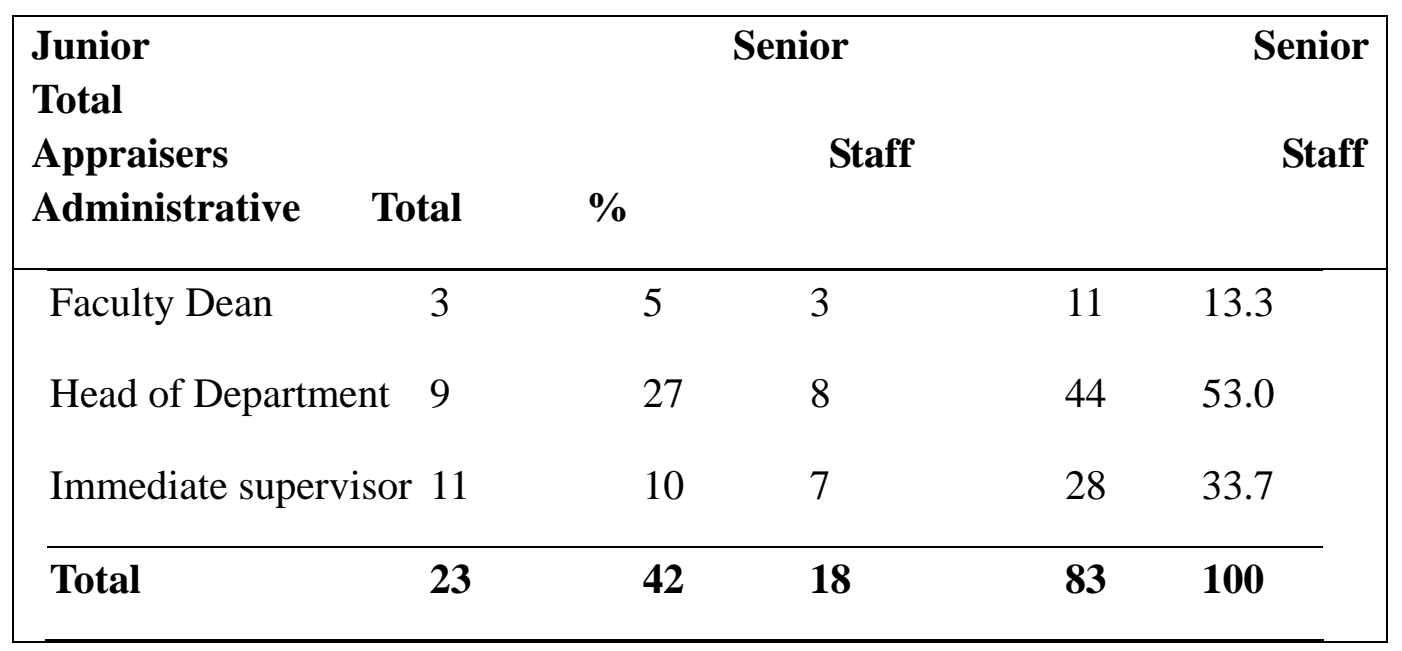

Source: Survey data, 2018

Reports in Table 6 projects Heads of Departments (HODs) as the highest (53\%) appraiser category in this study with immediate supervisors as the second highest group with $34 \%(\mathrm{n}=$ 28). Since the Deans' offices are predominantly administrative, the results here might be a confirmation of working with few staff (Faculty Registrar, Administrative Assistant, and Office Assistants).

\subsection{Research Question Four}

To what extent has performance appraisal in the UEW, Winneba Campus succeeded in identifying staff performance needs?

The final research question for the current study sought to measure employees' perceptions on whether UEW's performance appraisal exercise over the years has been used for performance needs. Four (4) response items for respondents to select on an ordinal scale (high extent, very moderate extent, moderate extent, low extent) were provided. Score of 1 to 4 respectively was used to code the responses.

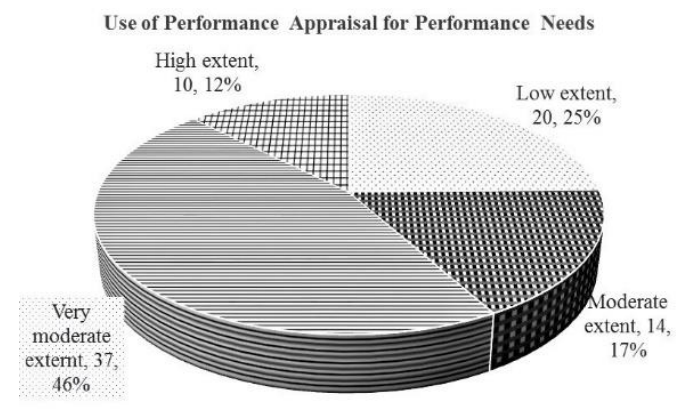

Figure 2. Extent of performance needs identification from UEW's PA system

Descriptively, figure 2 shows that $46 \%(\mathrm{n}=37)$ reported that UEW's performance appraisal system to a 'very moderate extent' covers performance needs of employees with nearly half $(42 \%, n=34)$ between 'low' and 'moderate' views. 


\section{Discussion}

For the first research question that sought to uncover the challenges that confront the management of UEW in conducting staff performance appraisal in the UEW, Winneba Campus, it was revealed that challenges such as fairness of evaluation decisions, discontentment between manger and appraisee, appraiser bias, lack of knowledge and skills of appraisers, access to appraisal forms, replacing organisational standards with appraise values and time in completing appraisal process affect the conduct of PA in UEW, Winneba Campus in conducting appraisal. It was also uncovered that the junior staff categories suffered more disaffection than the senior staff in the institution when it comes to appraisal issues.

The findings are in line with Ahmad and Bujang (2013) as well as Longenecker (1997) who opined that factors such as lack as fairness of evaluation decision, appraiser bias, lack of required skills and knowledge, subjectivity in evaluation, the practice of quota system, criticism and comments for unions, and inability of appraisal to suit organizational culture serve as a challenge when appraising employees' performance. Also, poor feedback and performance review sessions with employees and poor appraiser' training can cause ineffectiveness in some institutions. Smith (1990).

Again, the disaffection by the junior staff explains Singh's (2004) suggestion that the employee has the timely right to know the rudiments of the entire process while appraising and analysing their performance.

The second research question which sought to identify the factors and also rank the factors that contribute to an effective staff performance appraisal in UEW, Winneba Campus, uncovered that employee' performance, developmental needs of employees, assess performance of employees, identify strengths of employees, identify weaknesses of employees, performance gaps, control behaviour of employees and motivation contribute to making performance appraisal effective in the University of Education, Winneba. It was further revealed that factors such as decision making as annual salary increases and dismissals decisions do not contribute to making performance appraisal effective in the institution.

The findings of the study confirms the findings of Begum et al. (2015) and by Kim and Hoizer (2014) who indicated that rater accuracy and performance gaps, training and motivation, performance appraisal process, employee attitude, employees' participation, standard setting, quality of relationship they have with their supervisors, and employees' perceived empowerment affect the conduct of appraisal.

The results of the study also revealed that in order of importance, evaluating employees' performance, developmental needs of employees, assess performance of employees, identify strengths of employees, and identify weaknesses of employees and performance gaps are ranked higher in PA. Further the last four factors include control behaviour of employees, motivation, decision making on annual salary increases and dismissal decisions. These findings re-emphaises the positons of Agyenim-Boateng (2006), Kim and Hoizer (2014) and Cintron (2009) who were of the view that these factors as indicated are very important in the 
conduct of PA. It is in this regard that Begum et al. (2015) as well as Ochoti et al. (2012) stipulated these factors as critical when appraising employees' performance.

The third research question sought to uncover how often the University of Education, Winneba Campus, appraise their staff, the result of the study revealed that the UEW, Winneba Campus appraises its staff annually. In doing this, the results of the study further revealed and projects Heads of Departments (HODs) as the highest appraiser category in the UEW, Winneba campus with immediate supervisors as the second highest group. The finding confirms the position of Armstrong (2003) that performance appraisal in most firms are conducted once a year. The findings are also in line with Cascio (1996) who stressed that formal appraisal is done once or at best twice in a year.

On the contrary, Agyenim-Boateng (2006) and Khoury \& Analoui, (2004) claim different universities have different appraisal systems which are characterized by uncertainties and how they should be conducted. A successful implementation of good performance appraisal systems in institutions of higher learning will turn out highly competent and employable graduates to face the challenging competitive environment. Karuhanga \& Werner (2013).

For the last research question which was to find out the extent to which performance appraisal in the UEW, Winneba Campus has succeeded in identifying staff performance needs, the findings of the study uncovered that majority of the respondents see the extent to be very moderate in identifying their needs. This is evident because, according to Agyenim-Boateng (2006), Ahmad and Bujang (2013), Kim and Hoizer (2014), among several other writers, performance appraisal is very relevant in addressing employees' needs as well the overall development of the organization. The identification of employee needs will inform both administrative and developmental decisions to be taken.

\section{Conclusions and Recommendations}

\subsection{Conclusions}

The variations in the mean scores is indicative that the junior staff categories suffered more disaffection than the senior staff in the UEW, Winneba Campus.

In addition, some factors are regarded effective than others. The issue of evaluation of employees' performance and the developmental needs of employees were held in high esteem. However, the issue of performance gaps and motivation, as well as decision making on annual salary increases were least considered.

What constitutes performance appraisal of staff in the University varies depending on the status of the individual, however, there is a general view which ranks from evaluation of employees' performance to the developmental needs of employees.

Annual performance frequency as well as the working cycle of appraisal practices was dominant in the procedural strategies for staff performance appraisal in the University of Education, Winneba.

At the end of the year the heads of department were the topmost appraisers before the 


\section{Al Macrothink}

International Journal of Human Resource Studies

ISSN 2162-3058 2020, Vol. 10, No. 2

immediate supervisors and then the dean of the faculty within which the employee is working.

Performance appraisal is very important regarding employees' performance in the University.

\subsection{Recommendations for Policy and Practice}

For management to reap optimum benefit of performance appraisal systems, the University should focus on the evaluation of employees' performance, assessing their performance, as well as identifying their strengths and weakness to increase productivity and bring about cohesiveness.

The frequency and working cycle of employees regarding their performance should be strictly adhered to annually to ensure that employees are up and doing and be able to effectively address their challenges.

Also, Management must endeavour to ensure that the factors contributing to effective staff performance appraisal are considered carefully and implemented promptly. The suggestion that implementation of the factors indicated should be prompt dominates the respondents' ranking order of what constitutes performance appraisal system.

Again, for performance appraisal system to be made more functional, the University should ensure that the challenges associated with it are adequately dealt with. Taking into account the junior staff challenges where it is very crucial to allay all fears of non-performance due to these challenges to concentrate on other core duties of the University.

The University can also consider performance management methods which is a continuous process, that identifies, measures and develops the performance of individuals and teams and align their performance with strategic goals of the organization.

Finally, the University management should maintain and if possible improve on its mechanism in addressing and meeting the performance needs of employees. Though the study revealed a very moderate extent, the other extremes or outliers, are indication that there is still room for improvement.

\subsection{Suggestion for Further Research}

It is recommended that a similar study is conducted on other tertiary institutions to check how effective employees' performance appraisal is conducted in those institutions.

Also, future studies should consider the relationships among the performance appraisal systems in predicting employees' performance as well as their usage in performance appraisal.

\section{Acknowledgements}

We are very grateful to Prof. Eric Nyarko-Sampson, The Dean of Faculty of Educational Foundations, University of Cape Coast for his immense support throughout this period of study. 


\section{Macrothink}

International Journal of Human Resource Studies

ISSN 2162-3058 2020, Vol. 10, No. 2

\section{References}

Abrefa-Gyan, K. (2010). Performance appraisal, errors and weaknesses. Norfolk: Norfolk State University Press.

Adams, J. S. (1963). Wage inequities, productivity and work quality. Journal of Economy and Society, 3(1), 9-16. https://doi.org/10.1111/j.1468-232X.1963.tb00805.x

Agyenim-Boateng, E. O. (2006). An exploration into management of appraisal systems: the case of Ghanaian Public Universities. A PhD thesis presented to the University of Bradford.

Ahmad, R., \& Bujang, B. (2013). Issues and challenges in the practice of performance appraisal activities in the 21st Century. International Journal of Education and Research, $1(4), 1-8$.

Ampah, M. (2015). Introduction of performance appraisal: The case of UK and Ghana. Emerald Insight, 3(1), 99-110.

Armstrong, M. (2003). A handbook of human resource management practice ( $9^{\text {th }}$ ed.). London: Kogan Page.

Begum, S., Hossain, M., \& Sarker, M. A. S. (2015). Factors determining the effectiveness of performance appraisal system: A study on pharmaceutical industry in Bangladesh. The Cost and Management, 43, 15-27.

Cascio, W. F. (1996). The role of utility analysis in the strategic management of organizations. Journal of Human Resource Costing \& Accounting, 1(2), 85-95. https://doi.org/10.1108/eb029032

Cintron, R. (2009). Performance appraisal systems in higher education: an exploration of Cristian institutions. A dissertation submitted to the College of Education at the Universityof Central Florida Orlando, FL.

Creswell, J. W. (2008). Research design: Qualitative, quantitative and mixed methods approaches $\left(2^{\text {nd }}\right.$ ed.) California: Sage Publications.

Derek C. J., Panu, K., Takao, K., \& Kinen, K. (2005). People management and performance. Performance Review, 10(2), 20-28.

Gariatt Report. (1998). The World Health Report-Life in the $21^{\text {st }}$ century: A vision for all, WHO.

Gay, L. R., Mills, G., \& Airasian, P. (2009). Educational research: Competencies for analysis and applications. $\left(9^{\text {th }}\right.$ ed.). New Jersey: Pearson Education Ltd.

George, J. M., \& Jones, G. R. (1999). Understanding and Managing Organisational Behaviour, $5^{\text {th }}$ ed., Business and Economics, Addison-Wesley, Cornell University.

Hansen, D. (2003). Performance appraisal: Tips help page. Retrieved from: http://iso9k1.home.att.net/pa/performance-appraisal. Html. 


\section{Macrothink}

International Journal of Human Resource Studies ISSN 2162-3058 2020, Vol. 10, No. 2

Heathfeild, A. (2000) Performance Research, A journal of the Performing Arts, vol.5, www.tandfonline.comm

Karuhanga, B. N., \& Werner, A. (2013). Challenges impacting performance management implementation in public universities: A case of Uganda. African Journal of Economic and Management Studies, 4(2), 223-243. https://doi.org/10.1108/AJEMS-Nov-2011-0103

Khoury, G. C., \& Analoui, F. (2004). Innovative management model for performance appraisal: The case of the Palestinian public universities. Management Research News, 27(1/2), 56-73. https://doi.org/10.1108/01409170410784356

Kim, T., \& Hoizer, H. (2014). Public employees and performance appraisal: A study of antecedents to employees' perception of the process. Review of Public Personnel Administration, 36(1), 31 -56. https://doi.org/10.1177/0734371X14549673

Kumar, R. (1999). Research methodology: A step-by-step guide for beginners. California: Sage Publications.

Longenecker, C. O. (1997). Why managerial performance appraisals are ineffective: Causes and lessons. Journal of Career Development International, 2(5), 212-218. https://doi.org/10.1108/13620439710174606

Mathis, R. L., \& Jackson, J. H. (1994). Human resource management, ( $7^{\text {th }}$ ed.). Minneapolis, St Paul, West Pub. Co.

Mathis, R. L., \& Jackson, J. H. (2004). Human resource management, (10 ${ }^{\text {th }}$ ed.). South-Western, Ohio.

McLean, C. (2006). Questionnaire: Sage dictionary of social study methods. Available at: srmo.sagepub.com/view/the sage... of ....study-method/n168.xml. Retrieved on $23^{\text {rd }}$ August, 2017.

Mullins, L. J. (2005). Management and organisational behaviour $\left(7^{\text {th }}\right.$ ed.). London: Prentice hall.

Oberg, W. (1972). Make performance appraisal relevant in manage people, not personnel: motivation and performance appraisal. Boston: Harvard Business School Publishing Division.

Ochoti, G. N., Maronga, E., Muathe, S., Nyabwanga, N. R., \& Ronoh, K. (2012). Factors influencing employee performance appraisal system: A case of the Ministry of State for Provincial Administration \& Internal Security, Kenya. International Journal of Business and Social Science, 3(20), 37-46.

Ofori, D., \& Atiogbe, E. (2011). Strategic Planning in public universities: A developing country perspective. Journal of Management and Strategy, 3(1), 67-81. https://doi.org/10.5430/jms.v3n1p67

Pallant, J. (2010). SPSS survival manual. A step by step guide to data analysis using SPSS $4^{\text {th }}$ ed., Open University Press, McGraw Hill, Maidenhead. 


\section{Macrothink}

International Journal of Human Resource Studies

ISSN 2162-3058 2020, Vol. 10, No. 2

Planning Unit of the University of Education, Winneba. (2017). Statistics of the population parameters. Winneba: UEW.

Sarantakos, S. (2005). Social research ( $3^{\text {rd }}$ ed.). New York: Palgrave Mac-Millan. https://doi.org/10.1007/978-0-230-20901-5

Simmons, B. A. (2002). Capacity, commitment, and compliance: International institutions and territorial disputes. Journal of Conflict Resolution, 46(6), 829-856. https://doi.org/10.1177/002200202237931

Singh, K. (2004). Impact of HR practices on perceived firm performance in India. Asia Pacific Journal of Human Resources, 42(3), 301-317. https://doi.org/10.1177/1038411104048170

Smith, D. E. (1990) Training Programmes for performance appraisal: A review in Tim O. Peterson (Ed). Human Resource Management: Readings and cases. Houghton Mifflin, Boston Social Study Skills (2013). Study Methods: Questionnaires. Available at www.sociology.org.gh/method.pdf.

Swan, W. S. (1991). How to do superior performance appraisal. John Wiley: New York.

Teel, K. S. (1977). Performance appraisal: A survey of current practices. Personnel Journal, 56(5), 245-257.

Thibaut, J. W., \& Walker, L. (1975). Procedural justice: A psychological analysis. Hillsdale: L. Erlbaum Associates.

Torrington, D., Hall, L., \& Taylor, S. (2005). Human resource management. Essex: Prentice Hall/Financial Times

Vroom, V. H. (1964). Work and motivation. New York: Wiley.

Wilson, F. (2002). Dilemmas of appraisals. European Management Journal, 20(6), 620-622. https://doi.org/10.1016/S0263-2373(02)00113-5

\section{Copyright Disclaimer}

Copyright for this article is retained by the author(s), with first publication rights granted to the journal.

This is an open-access article distributed under the terms and conditions of the Creative Commons Attribution license (http://creativecommons.org/licenses/by/4.0/). 